\title{
Studi Perhitungan Indeks Keandalan Sistem Tenaga Listrik Menggunakan Graphical User Interface Matlab pada PT PLN (Persero) Rayon Kota Pinang
}

\author{
Adri Senen ${ }^{1}$; Titi Ratnasari²; Dwi Anggaini ${ }^{3}$ \\ ${ }^{1,2,3}$ Sekolah Tinggi Teknik PLN \\ 1ad_senen@yahoo.com \\ ${ }^{2}$ titi_ratnasari@yahoo.com \\ 32dwi_anggaini@sttpln.ac.id (corresponding authors)
}

\begin{abstract}
The level of reliability of a distribution system is very important to ensure the continuity of electricity supply to consumers. This research was conducted with the aim of calculating the Saidi reliability index and the Saifi $20 \mathrm{kV}$ distribution system in Pinang PLN in 2017 with the help of the Matlab R2008a application. A GUI is one of the matlab programs that is widely used in describing information and commands, and its users are possible to form and format themselves according to the needs of the system itself. With the help of this software, it is hoped that it will be easier to calculate the system reliability index, namely the calculation of SAIDI and SAIFI, then the results can be made so that the database is more organized. The calculation results obtained will show the highest and lowest SAIDI and SAIFI values that occur in each of the current months, making it easier to evaluate, analyze and improve the reliability of the electrical power system network in the future, especially in PT.
\end{abstract}

Keywords: Reliability, Matlab R2008a, GUI, SAIDI and SAIFI

\begin{abstract}
ABSTRAK
Tingkat keandalan dari suatu system distribusi merupakan hal yang sangat penting untuk menjamin kontuinitas supply tenaga listrik kepada konsumen. Penelitian ini dibuat dengan tujuan menghitung indeks keandalan Saidi dan Saifi system distibusi 20 kV di PLN Kota Pinang tahun 2017 dengan bantuan aplikasi Matlab R2008a. GUI merupakan salah satu program matlab yang banyak digunakan dalam menggambarkan suatu informasi dan perintah, dan penggunanya dimungkinkan uttuk meraacang sendiri bentuk dan format sesuai kebutuhan sistem itu sendiri. Dengan bantuan software ini nantinya diharapkan lebih memudahkan dalam perhitugan indeks keandalalan sistem yaitu perhitungan SAIDI dan SAIFI, kemudian hasilnya bisa dibuatkan database nya sehingga lebih tertata rapi. Hasil perhitungan yang diperoleh akan memperlihatkan nilai SAIDI dan SAIFI tertinggi dan terendah yang terjadi di tiap-tiap bulan berjalan, sehingga memudahkan dalam melakukan eavaluasi, analisa dan peningkatan keandalan jaringan sistem tenaga listrik kedepannya khususnya di PT.PLN Persero Rayon Kota Pinang dikategorikan masih handal.
\end{abstract}

Kata kunci: Keandalan, Matlab R2008a, GUI, SAIDI dan SAIFI

138 | Energi dan Kelistrikan: Jurnal Ilmiah 


\section{PENDAHULUAN}

Secara umum keandalan sistem tenaga listrik dapat didefinisikan sebagai suatu kemampuan sistem untuk memberikan suatu pasokan tenaga listrik yang cukup dengan kualitas yang memuaskan. Faktor yang sangat mempengaruhi dari kualitas energi listrik yang dipakai adalah kestabilan tegangan, frekuensi, kontinuitas pelayanan, dan faktor daya. Namun dari beberapa faktor diatas yang sangat dirasakan oleh pelanggan adalah kontinuitas pelayanan energi listrik, karena banyak keluhan dari para pelanggan mengenai sering terjadi pemadaman listrik dalam waktu yang lama. Sehingga para pelanggan listrik baik pelanggan besar maupun pelanggan kecil akan merasakan akibatnya. Semakin meningkatnya kebutuhan akan tenaga listrik, menuntut suatu sistem tenaga listrik yang mempunyai keandalan dalam penyediaan dan penyaluran dayanya pada suatu jaringan distribusi. Indeks-indeks yang digunakan untuk mengetahui tingkat keandalan suatu sistem distribusi antara lain adalah SAIFI (System Average Interruption Frequency Index), SAIDI (System Average Interruption Duration Index), CAIFI (Consumer Average Interruption Frequency Index) dan CAIDI (Customer Average Interruption Duration Index).

SAIDI (System Average Interruption Duration Indeks) Merupakan jumlah dari perkalian lama padam dengan pelanggan yang padam dibagi dengan jumlah pelanggan yang dilayani. Atau Lama Padam Rata-rata (LPR = SAIDI) dalam satuan $\mathrm{x}$ jam/tahun, $\mathrm{x}$ jam/bulan atau $\mathrm{x}$ jam/kuartal. Menurut IEEE istilah yang digunakan adalah SAIDI (System Average Interruption Duration Index). Sedangkan SAIFI (System Average Interruption Frequency Indeks) merupakan nilai Indeks rata-rata frekuensi gangguan pada sistem. SAIFI adalah rata-rata jumlah interupsi atau gangguan yang berkelanjutan per konsumen sepanjang tahun. Ini adalah rasio jumlah interupsi atau gangguan tahunan terhadap jumlah konsumen.

. Skripsi ini bertujuan untuk menganalisa keandalan sistem distribusi tenaga listrik tersebut termasuk saidi dan saifi yang berdasarkan durasi atau lamanya pemadaman dan berapa kali jumlah pemadaman dalam kurun waktu tertentu. Perhitungan indeks keandalan secara keseluruhan dilakukan dengan menggunnakan aplikasi MATLAB R2008a.

GUI merupakan singkatan dari Graphical User Interface, sebuah aplikasi display dari MATLAB yang mengandung tugas, perintah, atau komponen program yang mempermudah user (pengguna) dalam menjalankan sebuah program dalam MATLAB. Tujuan penggunaan aplikasi Matlab ini adalah untuk memudahkan dalam perhitungan termasuk perhitungan saidi dan saifi, selain itu juga dapat menampilkan suatu data dalam bentuk grafik.

\section{METODE/PERANCANGAN PENELITIAN}

\subsection{Analisa kebutuhan}

Pada skripsi ini dibutuhkan beberapa data untuk memenuhi hasil dari penulisan. Data yang dibutuhkan yaitu data system, jenis komponen, penyebab gangguan serta data-data yang pendukung lainnya yaitu data dari total pelanggan, lama padam atau lamanya gangguan yang terjadi, jumlah gangguan yang terjadi, jumlah pelanggan yang padam atau yang terkena gangguan dan juga nilai dari Saidi dan Saifi yang sudah ditetapkan di PT. PLN (Persero) Rayon Kota Pinang pada tahun 2017.

\subsection{Perancangan Penelitian}

Langkah pertama yaitu menggunakan teknik observasi sebagai alat dalam pengumpulan data, untuk selanjutnya data tersebut akan diolah menggunakan aplikasi Matlab R2008a dan dianalisis sesuai dengan teori yang digunakan.

Langkah kedua adalah melakukan perhitungan dan kemudian pembuatan laporan serta pengambilan kesimpulah terhadap data yang sudah dihitung dalam bentuk Aplikasi Matlab R2008a. 
Secara sederhana perencanaan penelitian yang dilakukan tergambar dalam diagram alir sebagai berikut:

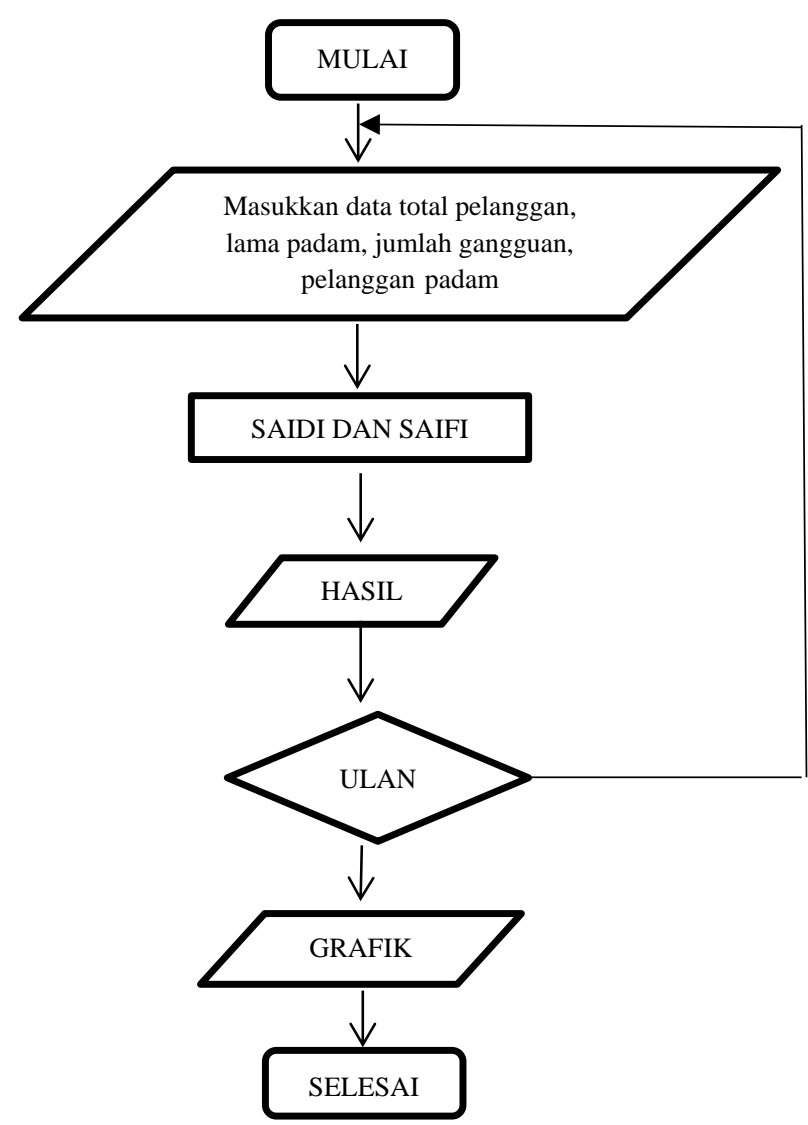

Gambar 1. Diagram Alir (Flowcart) Penelitian

\subsection{Perancangan Perhitungan Saidi Dan Saifi}

SAIFI adalah indeks keandalan yang merupakan jumlah dari perkalian frekuensi padam danpelanggan padam dibagi dengan jumlah pelanggan yang dilayani. Dengan indeks ini gambaran mengenai frekuensi kegagalan rata-rata yang terjadi pada bagian-bagian dari sistem biasa dievaluasi sehingga dapat dikelompokkan sesuai dengan tingkat keandalannya. Satuannya adalah pemadaman per pelanggan. Secara matematis dapat dirumuskan sebagai berikut:

$f=\frac{\sum_{i=1}^{m} C i x l i}{N}$

Dimana:

li $=$ Pemadaman $/$ Gangguan

$\mathrm{m}=$ Jumlah pemadaman dalam satu tahun

$\mathrm{Ci}=$ Jumlah konsumen yang mengalami pemadaman

$\mathrm{N}=$ Jumlah konsumen yang dilayani.

SAIDI adalah indeks keandalan yang merupakan perkalian dari lamanya suatu sistem padam dalam hitungan jam dengan banyaknya pelanggan yang mengalami pemadaman dibagi dengan jumlah pelanggan keseluruhan. Satuan perhitungan SAIFI adalah jam/pelanggan. Dengan indeks ini, 
gambaran mengenai lama pemadaman rata-rata yang diakibatkan oleh gangguan pada bagian-bagian dari sistem dapat dievaluasi. Secara matematis dapat dirumuskan sebagai berikut:

$d=\frac{\sum_{i=1}^{m} \operatorname{Cix} t i}{N}$

Dimana:

$\mathrm{m}=$ Jumlah pemadaman dalam satu tahun

$\mathrm{ti}=$ lamanya tiap-tiap pemadaman

$\mathrm{Ci}=$ Jumlah konsumen yang mengalami pemadaman

$\mathrm{N}=$ Jumlah konsumen yang dilayani

\subsection{Perancangan Graphical User Interface (GUI)}

Command Window merupakan dasar pemrograman pada Matlab. Matlab menyediakan m-file, yaitu suatu file yang berisi kode program. Ada dua jenis yaitu script dan function. Dan yang digunakan adalah function. Sementara itu command window digunakan untuk menguji apakah suatu kode dapat berjalan dalam m-file. Suatu fungsi M-File harus mengikuti beberapa aturan. Fungsi Mfile juga mempunyai sejumlah sifat penting. Aturan-aturan dan sifat-sifat tersebut meliputi:

1. Pertama kali MATLAB mengeksekusi suatu fungsi M-file, MATLAB membuka file fungsi tersebut dan mengkompilasi perintah-perintah di dalamnya menjadi suatu representasi internal dalam memori yang mempercepat eksekusi untuk semua pemanggilan berikutnya. Jika fungsi juga melibatkan pemanggilan ke fungsi M-file yang lain, fungsi M-file yang dipanggil itu juga akan dikompilasi ke dalam memori.

2. Setiap fungsi memiliki ruang kerjanya sendiri yang berbeda dengan ruang kerja MATLAB. Satu-satunya hubungan antara ruang kerja MATLAB dengan variabel-variabel dalam fungsi adalah variabel-variabel input dan output fungsi. Jika suatu fungsi mengubah nilai dalam bentuk suatu variabel input, perubahan itu hanya tampak dalam fungsi dan tidak mempengaruhi ruang kerja MATLAB.

3. Fungsi dapat berbagi variabel dengan fungsi lain, ruang kerja MATLAB dan pemanggilan rekursi untuk dirinya sendiri jika variabelnya dideklarasikan sebagai variabel global.

4. Fungsi M-file berhenti dieksekusi dan kembali ke prompt jika telah mencapai akhir dari M-file atau jika menemui perintah return.

\subsection{Teknik Analisis}

Setelah rangkaian data terkumpul, selanjutnya dilakukan analisis data dengan prosedur dan teknis pengolahan sebagai berikut:

1. Melakukan pemilahan dan penyusunan klasifikasi data.

Dari data yang didapat, disusun berdasarkan klarifikasi, bisa berdasarkan tertinggi, terendah, terbanyak atau paling sedikit.

2. Melakukan konfirmasi data dan pendalaman data.

Data yang sudah didapat, dipelajari bagaimana cara pembacaan data tersebut dengan benar.

3. Melakukan perhitungan menggunakan aplikasi Matlab R2008a.

Dalam perhitungan data atau olah data begitu juga dengan grafik menggunakan Aplikasi Matlab R2008a.

4. Melakukan analisis data sesuai dengan konstruksi pembahasan hasil penelitian.

Setelah data diolah atau dihitung,selanjutnya data tersebut dievaluasi atau juga dianalisa 
5. Selanjutnya akan diambil kesimpulan mengenai data yang sudah diolah dan juga memberikan masukan terhadap hasil dan pembahasan yang sudah dilakukan.

Setelah data tadi diolah dan juga dianalisa, selanjutnya diambil kesimpulan berdasarkan hasil olahan tersebut.

\section{HASIL DAN PEMBAHASAN}

\subsection{Data}

Data-data lapangan dirangkum kedalam Tabel 2 yang merupakan data pelanggan dan hasil monitoring gangguan yang terjadi pada PT.PLN (Persero) Rayon Kota Pinang yang terdiri dari 4 feeder yakni KP01, KP02, KP03, dan KP04. Berdasarkan data-data inilah dilakukan perhitungan untuk mengetahui berapa besar SAIDI dan SAIFI. Nilai SAIDI dan SAIFI didapat dam kemudian dibandingkan dengan standar PLN Kota Pinang, dimana standar yang digunakan diangka 5,08 jam/pelanggan/tahun untuk SAIDI dan 2,88 pemadaman/pelanggan/tahun untuk SAIFI.

Tabel 1. Data pelanggan dan laporan monitoring gangguan sistem distribusi PT.PLN (Persero) Kotapinang selama Tahun 2017 Berdasarkan Penyebab Gangguan

\begin{tabular}{|c|l|c|c|c|c|c|}
\hline No & Bulan & $\begin{array}{c}\text { Total } \\
\text { Pelanggan } \\
(N)\end{array}$ & $\begin{array}{c}\text { Jumlah } \\
\text { Gangguan } \\
(\text { li })\end{array}$ & $\begin{array}{c}\text { Lama } \\
\text { Gangguan } \\
\left(t_{i}\right)\end{array}$ & $\begin{array}{c}\text { Kwh tidak } \\
\text { tersalur }\end{array}$ & $\begin{array}{c}\text { Jumlah } \\
\text { Pelanggan } \\
\text { Padam }(\mathrm{C} i)\end{array}$ \\
\hline 1 & Januari & 57.512 & 19 & 26,79 & 5 & 19 \\
\hline 2 & Februari & 58.105 & 27 & 6,84 & 6,865 & 97 \\
\hline 3 & Maret & 58.285 & 15 & 4,55 & 897 & 12 \\
\hline 4 & April & 58.674 & 5 & 10,01 & 2 & 5 \\
\hline 5 & Mei & 59.046 & 13 & 5,67 & 3 & 13 \\
\hline 6 & Juni & 59.209 & 17 & 5,99 & 9 & 180 \\
\hline 7 & Juli & 59.384 & 6 & 1,29 & 2 & 6 \\
\hline 8 & Agustus & 59.713 & 2 & 0,48 & 2 & 2 \\
\hline 9 & September & 59.968 & 20 & 7,10 & 1 & 20 \\
\hline 10 & Oktober & 60.172 & 15 & 4,28 & 4 & 16 \\
\hline 11 & November & 60.614 & 14 & 3,45 & 1 & 14 \\
\hline 12 & Desember & 61.425 & 16 & 3,65 & 2 & \\
\hline
\end{tabular}

Tabel 2. Jumlah pelanggan padam berdasarkan penyebab gangguan

\begin{tabular}{|l|l|l|}
\hline No & \multicolumn{1}{|c|}{ Penyebab Gangguan } & $\begin{array}{c}\text { Jumlah Pelanggan } \\
\text { Padam }\end{array}$ \\
\hline 1 & Kelompok Padam Tidak Terencana & \\
\hline & 1. Gardu Induk & 0 \\
\hline & 2. Fasilitas Penyulang & 109.946 \\
\hline & 3. Gardu Distribusi & 12.979 \\
\hline & 4. Jaringan TR & 130 \\
\hline 2 & Kelompok Pambungan Tenaga Listrik dan APP & 25 \\
\hline & 1. Gardu Induk & \\
\hline & 2. Fasilitas Penyulang & 0 \\
\hline
\end{tabular}




\begin{tabular}{|l|l|l|}
\hline & 3. Gardu Distribusi & 0 \\
\hline & 4. Jaringan TR & 3 \\
\hline & 5. Sambungan Tenaga Listrik dan APP & 3 \\
\hline 3 & Kelompok Bencana Alam & 0 \\
\hline 4 & Kelompok Transmisi & 0 \\
\hline 5 & Kelompok Pembangkit & 0 \\
\hline 6 & TOTAL & $\mathbf{1 2 3 . 0 8 6}$ \\
\hline
\end{tabular}

Jumlah pelanggan yang mengalami pemadaman sepanjang tahun 2017 mencapai 123.086 pelanggan. Kelompok padam tidak terencana pada pemeliharaan fasilitas penyulang memberikan kontribusi yang besar sebagai penyebab pemadaman sepanjang tahun 2017 yaitu 109.946 pelanggan padam.

\subsection{Perhitungan SAIDI dan SAIFI menggunakan GUI MATLAB R2008A}

Untuk perhitungan nilai Saidi dan Saifi, berikut tampilan GUI (Graphical User Interface) Matlab R2008a.

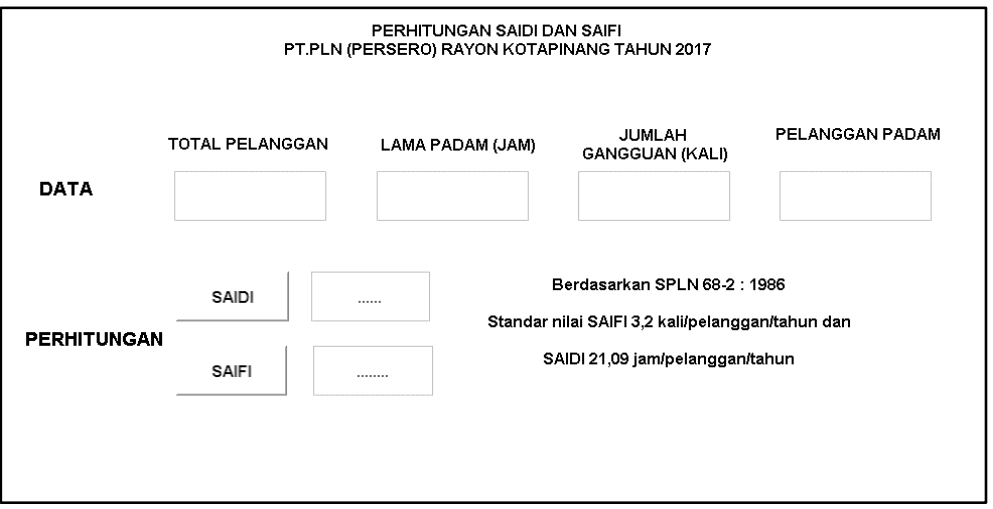

Gambar 2. Perhitungan Saidi dan Saifi dengan tampilan GUI Matlab R2008a

Dalam membuat GUI seperti gambar diatas dibutuhkan beberapa handles seperti pushbutton, edit text dan static text. Namun untuk membuatnya agar berjalan (Running) maka harus menggunakan m.file yang sesuai. Dengan memasukkan data seperti total pelanggan, pelanggan padam, jumlah gangguan dan lamanya gangguan pada kolom yang kosong diatas, maka dengan menekan tombol saidi dan saifi maka akan muncul nilai saidi dan saifi yang sudah dihitung secara otomatis berdasarkan m.file yang digunakan. Berikut hasil perhitungan Saidi dan Saifi bulan Januari s/d Desember yang akan ditampilkan dalam bentuk Graphical User Interface (GUI), sebagai contoh: 


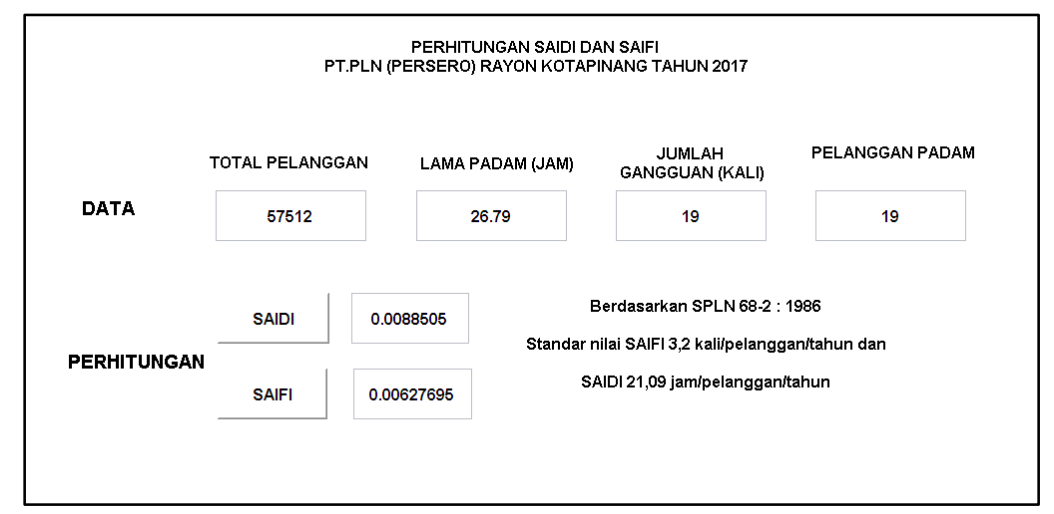

Gambar 3. Perhitungan SAIDI dan SAIFI pada bulan Januari dengan tampilan GUI Matlab R2008a

Berdasarkan perhitungan diatas, indeks keandalan SAIDI dan SAIFI pada PT. PLN (Persero) Rayon Kota Pinang periode bulan Januari 2017 sampai dengan Desember 2017 secara lengkap disajikan pada Tabel 3.

Tabel 3. Indeks Keandalan SAIDI dan SAIFI periode Januari - Desember tahun 2017 PT.PLN (Persero) Rayon Kota Pinang

\begin{tabular}{|l|c|c|}
\hline \multirow{2}{*}{ Bulan } & \multicolumn{2}{c|}{ Indeks Keandalan } \\
\cline { 2 - 3 } & SAIDI & SAIFI \\
\hline Januari & 0,0088 & 0,006 \\
\hline Februari & 0,0114 & 0,04 \\
\hline Maret & 0,0009 & 0,003 \\
\hline April & 0,0008 & 0,0004 \\
\hline Mei & 0,0012 & 0,002 \\
\hline Juni & $\mathbf{0 , 0 1 8 2}$ & $\mathbf{0 , 0 5}$ \\
\hline Juli & 0,0001 & 0,0006 \\
\hline Agustus & $\mathbf{0 , 0 0 0 0 1 6}$ & $\mathbf{0 , 0 0 0 0 6}$ \\
\hline September & 0,0023 & 0,0006 \\
\hline Oktober & 0,0068 & 0,02 \\
\hline November & 0,0009 & 0,003 \\
\hline Desember & 0,0008 & 0,003 \\
\hline
\end{tabular}

Untuk Grafik nilai SAIDI dan SAIFI yang sudah dihitung dapat ditunjukan pada gambar berikut:

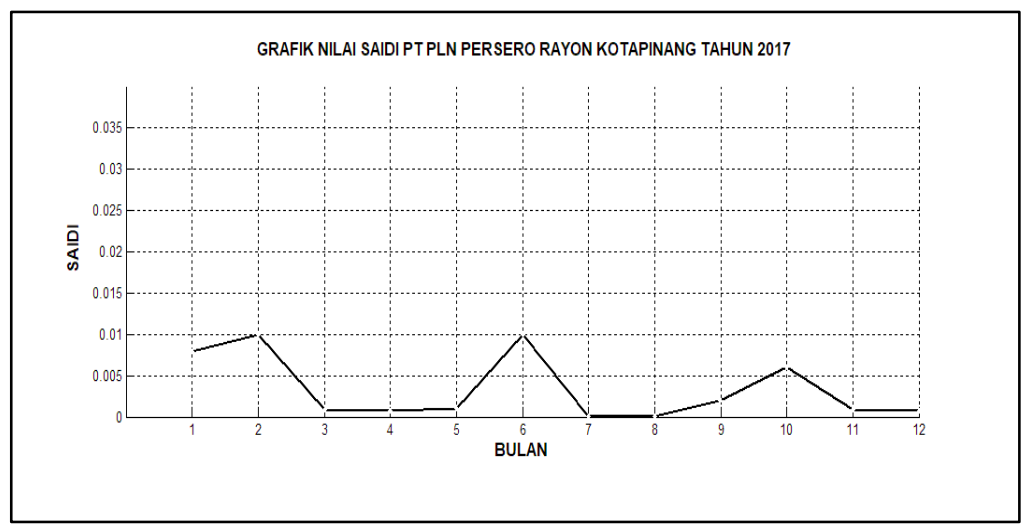

Gambar 4. Grafik nilai SAIDI berdasarkan hasil perhitungan bulan Januari s/d Desember 2017 pada PT.PLN Persero Rayon Kotapinang 


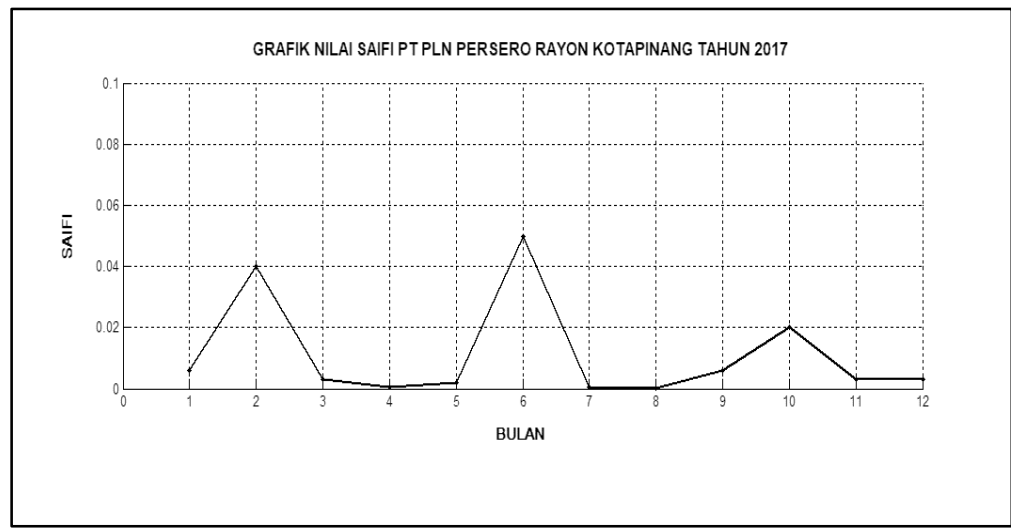

Gambar 5. Grafik nilai SAIFI berdasarkan hasil perhitungan bulan Januari s/d Desember 2017 pada PT.PLN Persero Rayon Kotapinang

Untuk perbandingan antara nilai SAIDI dan SAIFI dapat dilihat pada gambar dibawah ini:

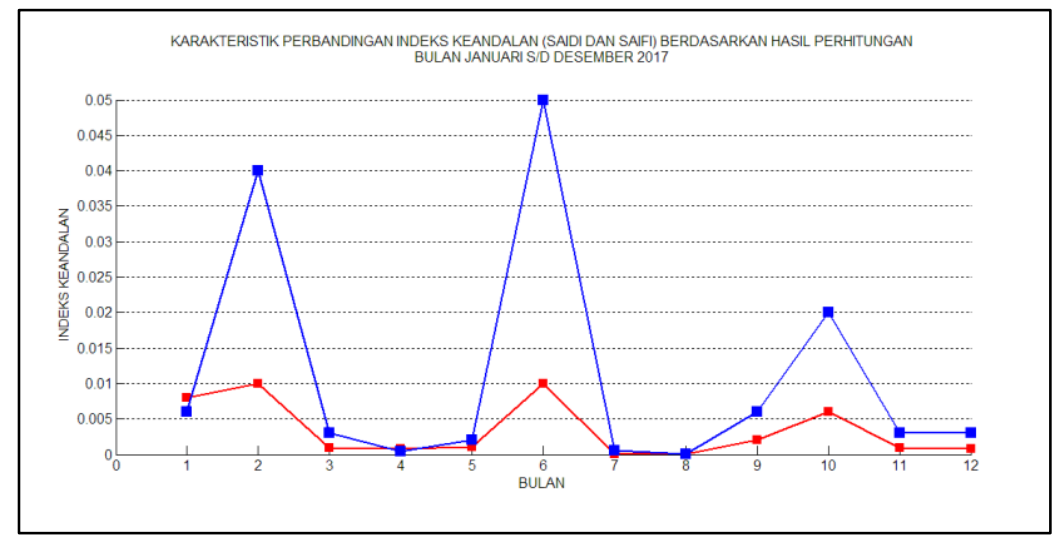

Gambar 6. Grafik perbandingan nilai SAIFI dan SAIDI berdasarkan hasil perhitungan bulan Januari s/d Desember 2017 pada PT.PLN Persero Rayon Kotapinang

Keterangan: Tanda berwarna merah menunjukkan nilai saidi dan biru menunjukkan nilai saifi

\subsection{Analisa}

Berdasarkan data yang didapat, bulan Januari jumlah pelanggan sebanyak 57.512 pelanggan, dengan jumlah pelanggan yang terkena gangguan sebanyak 19 pelanggan, terjadinya gangguan sebanyak 19 kali dan lama gangguannya selama 26,79 jam. Dengan data tersebut ditargetkan bahwa pada bulan Januari nilai indeks SAIDI dan SAIFI berturut-turut di angka 5,08 jam/pelanggan/tahun dan 2,88 kali/pelanggan/tahun. Setelah dilakukan perhitungan, didapat bahwa nilai SAIDI dan SAIFI pada bulan Januari di angka $\mathbf{0 , 0 0 8 8}$ dan $\mathbf{0 , 0 0 6}$. Pada bulan Januari terjadi beberapa kerusakan pada bagian fasilitas distribusi, diantaranya kerusakan pada bagian Jaringan Tegangan Rendah seperti kabel JTR dan kabel primer/sekunder. Hal ini diakibatkan oleh gangguan hewan dan juga gangguan dari pohon yang tumbang. Solusi yang dilakukan ialah dengan pemeliharaan yaitu penebangan pohon disekitar lokasi kerusakan sehingga mengurangi gangguan. Selain itu juga dilakukan pemasangan tekep isolator dengan tujuan untuk melindungi isolator dari konduksi selain itu tekep isolator juga terbuat dari bahan plastic sehingga tidak akan merusak jaringan SUTM.

Pada bulan Februari jumlah pelanggan sebanyak 58.105 pelanggan, dengan jumlah pelanggan yang terkena gangguan sebanyak 97 pelanggan, terjadinya gangguan sebanyak 27 kali dan lama 
gangguannya selama 6,84 jam. Dengan data tersebut ditargetkan bahwa pada bulan Februari nilai indeks SAIDI dan SAIFI berturut-turut di angka $\mathbf{5 , 0 8}$ jam/pelanggan/tahun dan $\mathbf{2 , 8 8}$ kali/pelanggan/tahun. Setelah dilakukan perhitungan, di dapat bahwa nilai SAIDI dan SAIFI pada bulan Februari di angka 0,0114 dan 0,04. Ada beberapa gangguan yang terjadi di beberapa bagian fasilitas SUTM, yakni pada konduktor dan kabel primer/sekunder. Terdapat sebanyak 5 buah kabel primer/sekunder yang rusak dan 17 konduktor yang mengalami kerusakan juga. Hal ini diakibatkan oleh gangguan hewan dan pohon disekitar lokasi gangguan. Solusi untuk mengatasinya ialah dengan penumbangan pohon yang mengganggu jaringan dan juga pemasangan tekep isolator.

Berdasarkan data yang didapat pada bulan Maret jumlah pelanggan sebanyak 58.285 pelanggan, dengan jumlah pelanggan yang terkena gangguan sebanyak 12 pelanggan, terjadinya gangguan sebanyak $15 \mathrm{kali}$ dan lama gangguannya selama 4,55 jam. Dengan data tersebut ditargetkan bahwa pada bulan Maret nilai indeks SAIDI dan SAIFI berturut-turut di angka 5,08 jam/pelanggan/tahun dan $\mathbf{2 , 8 8} \mathrm{kali} /$ pelanggan/tahun. Setelah dilakukan perhitungan, di dapat bahwa nilai SAIDI dan SAIFI pada bulan Maret di angka 0,0009 dan 0,003. Gangguan yang terjadi hanya terjadi di bagian kabel JTR.Terdapat sebanyak 11 buah kabel JTR yang mengalami kerusakan. Hal ini juga diakibatkan oleh gangguan hewan dan pohon. Solusi utama ialah dengan penggantian kabel yang baru.

Berdasarkan data yang didapat pada bulan Mei jumlah pelanggan sebanyak 59.046 pelanggan, dengan jumlah pelanggan yang terkena gangguan sebanyak 13 pelanggan,terjadinya gangguan sebanyak 13 kali dan lama gangguannya selama 5,67 jam. Dengan data tersebut ditargetkan bahwa pada bulan Mei nilai indeks SAIDI dan SAIFI berturut-turut di angka 5,08 jam/pelanggan/tahun dan $\mathbf{2 , 8 8}$ kali/pelanggan/tahun. Setelah dilakukan perhitungan, di dapat bahwa nilai SAIDI dan SAIFI pada bulan Mei di angka 0,0012 dan 0,002. Beberapa gangguan diakibatkan oleh kerusakan pada kabel JTR sebanyak 10 buah, namun ada juga kerusakan pada PHBTR. PHB TR adalah terminal pembagi dari trafo pada gardu listrik ke jaringan rumah tangga. Untuk itu dilakukan penggantian kabel yang baru.

Berdasarkan data yang didapat, bulan Juni jumlah pelanggan sebanyak 59.209 pelanggan,dengan jumlah pelanggan yang terkena gangguan sebanyak 180 pelanggan, terjadinya gangguan sebanyak 17 kali dan lama gangguannya selama 5,99 jam. Dengan data tersebut ditargetkan bahwa pada bulan Juni nilai indeks SAIDI dan SAIFI berturut-turut di angka 5,08 jam/pelanggan/tahun dan $\mathbf{2 , 8 8}$ kali/pelanggan/tahun. Setelah dilakukan perhitungan, di dapat bahwa nilai SAIDI dan SAIFI pada bulan Juni di angka $\mathbf{0 , 0 1 8 2}$ dan $\mathbf{0 , 0 5}$. Beberapa gangguan terjadi di bagian fasilitas distribusi, yakni kerusakan pada trafo. Hal ini diakibatkan oleh kelebihan beban sehingga menimbulkan kerusakan pada trafo. Hal yang harus dilakukan adalah dengan penggantian dan pemeliharaan. Jika trafo tersebut rusak karena ledakan, maka trafo tersebut harus diganti, namun jika trafo tersebut hanya mengalami kebocoran minyak, maka dilakukan pemeliharaan.

Berdasarkan data yang didapat, bulan Juli jumlah pelanggan sebanyak 59.384 pelanggan, dengan jumlah pelanggan yang terkena gangguan sebanyak 6 pelanggan, terjadinya gangguan sebanyak 6 kali dan lama gangguannya selama 1,29 jam. Dengan data tersebut ditargetkan bahwa pada bulan Juli nilai indeks SAIDI dan SAIFI berturut-turut di angka $\mathbf{5 , 0 8} \mathrm{jam} /$ pelanggan/tahun dan $\mathbf{2 , 8 8}$ kali/pelanggan/tahun. Setelah dilakukan perhitungan, di dapat bahwa nilai SAIDI dan SAIFI pada bulan Juli di angka 0,0001 dan 0,0006. Kerusakan terjadi pada MV Cell yang disebabkan oleh hewan dan korona. Untuk solusinya, MV cell tersebut diganti dengan yang baru.

Pada bulan September jumlah pelanggan sebanyak 59.968 pelanggan, dengan jumlah pelanggan yang terkena gangguan sebanyak 20 pelanggan, terjadinya gangguan sebanyak 20 kali dan lama gangguannya selama 7,10 jam. Dengan data tersebut ditargetkan bahwa pada bulan September 
nilai indeks SAIDI dan SAIFI berturut-turut di angka $\mathbf{5 , 0 8}$ jam/pelanggan/tahun dan $\mathbf{2 , 8 8}$ kali/pelanggan/tahun. Setelah dilakukan perhitungan, didapat bahwa nilai SAIDI dan SAIFI pada bulan September di angka 0,0023 dan 0,006. Beberapa kegagalan terjadi di bagian fasilitas JTR, diantaranya kabel JTR dan PHBTR. Kegagalan tersebut diakibatkan oleh pohon yang tumbang dan bisa juga diakibatkan oleh hewan. Selain itu kegagalan lain terjadi dibagian sambungan tenaga listrik dan APP yakni pada kabel SR dan APP.

Berdasarkan data yang didapat di bulan Oktober jumlah pelanggan sebanyak 60.172 pelanggan, dengan jumlah pelanggan yang terkena gangguan sebanyak 97 pelanggan, terjadinya gangguan sebanyak 15 kali dan lama gangguannya selama 4,28 jam. Dengan data tersebut ditargetkan bahwa pada bulan Oktober nilai indeks SAIDI dan SAIFI berturut-turut di angka 5,08 jam/pelanggan/tahun dan $\mathbf{2 , 8 8} \mathrm{kali} /$ pelanggan/tahun. Setelah dilakukan perhitungan, di dapat bahwa nilai SAIDI dan SAIFI pada bulan Oktober di angka 0,0068 dan 0,02. Beberapa kegagalan terjadi di bagian fasilitas JTR, diantaranya kabel JTR dan PHBTR. Kegagalan tersebut diakibatkan oleh pohon yang tumbang dan bisa juga diakibatkan oleh hewan. Selain itu kegagalan lain terjadi dibagian sambungan tenaga listrik dan APP yakni pada kabel SR dan APP.

Berdasarkan data yang didapat, bulan Desember jumlah pelanggan sebanyak 61.425 pelanggan, dengan jumlah pelanggan yang terkena gangguan sebanyak 14 pelanggan, terjadinya gangguan sebanyak 16 kali dan lama gangguannya selama 3,65 jam. Dengan data tersebut ditargetkan bahwa pada bulan Desember nilai indeks SAIDI dan SAIFI berturut-turut diangka 5,08 jam/pelanggan/tahun dan 2,88 kali/pelanggan/tahun. Setelah dilakukan perhitungan, di dapat bahwa nilai SAIDI dan SAIFI pada bulan Desember di angka 0,0008 dan 0,003. Kerusakan terjadi pada kabel JTR dan juga kabel SR.Kerusakan tersebut diakibatkan oleh pohon dan hewan di daerah sekitar kabel JTR dan kabel SR tersebut. Untuk itu dilakukan pemeliharaan dengan penebangan pohon yang mengganggu.

SAIDI terendah dicapai pada bulan Agustus di angka 0,000016 dan nilai SAIDI tertinggi terjadi di bulan Juni dengan nilai sebesar 0,0182. Sedangkan untuk SAIFI terendah terjadi di bulan Agustus dengan nilai sebesar 0,00006 dan tertinggi terjadi di bulan Juni dengan nilai sebesar 0,05.

\section{KESIMPULAN DAN SARAN}

\subsection{Kesimpulan}

Berdasarkan hasil yang didapat dari perhitungan dan analisis pada skripsi ini, didapat kesimpulan sebagai berikut:

1. Berdasarkan hasil perhitungan menggunakan Aplikasi Matlab R2008a didapat nilai SAIDI sebesar 0,00005 jam per pelanggan per tahun dan telah sesuai dengan standar PLN yaitu $21 \mathrm{jam} /$ tahun. Untuk nilai SAIFI yang dihitung berada diangka 0,0081 kali per pelanggan per tahun dan telah sesuai dengan standar PLN yaitu 3,2 kali/tahun.

2. Nilai SAIDI tertinggi terjadi di bulan Juni sebesar 0,0182 jam per pelanggan per bulan dan terendah di bulan Agustus sebesar 0,000016 per pelanggan per bulan dan telah sesuai dengan Standar PLN sebesar 1,75 jam /bulan atau 21 jam/tahun.

3. Nilai SAIFI tertinggi terjadi di bulan Februari sebesar 0,0004 kali per pelanggan per bulan dan nilai SAIFI terendah di bulan Agustus sebesar 0,00003 per pelanggan per bulan dan telah susuai dengan Standar PLN yaitu sebesar 3,2 kali/tahun atau 0,2 kali /bulan.

4. Kegagalan yang sering terjadi diakibatkan oleh kegagalan non-teknis dan juga secara teknis seperti gangguan pohon, gangguan hewan dan juga gangguan sistem. Sehingga sering terjadi terputusnya kabel saluran, baik itu JTR, kabel sekunder/primer maupun kabel SR, dan juga kerusakan Trafo. 
5. Pemakaian aplikasi Matlab R2008a merupakan bentuk penyederhanaan perhitungan SAIDI dan SAIFI. Pemakaian aplikasi ini juga bisa digunakan untuk penyederhanaan perhitungan lainnya.

\subsection{Saran}

Berdasarkan kesimpulan dari hasil penelitian ini penulis menyarankan kepada pihak penyedia listrik khususnya di PT. PLN (Persero) Rayon Kota Pinang agar meningkatkan jadwal pemeliharaan pada saluran khususnya saluran udara tegangan menengah (SUTM) agar gangguan yang disebabkan oleh pohon/dahan kayu yang sudah mengenai saluran listrik dapat dikurangi.

\section{UCAPAN TERIMAKASIH}

Penulis mengucapkan terima kasih kepada Instansi/perusahaan/lembaga yang telah memberi dukungan yang membantu pelaksanaan penelitian dan atau penulisan artikel.

\section{DAFTAR PUSTAKA}

[1] Doloksaribu. 2010. Parlindungan Analisa Keandalan Sistem Distribusi Tenaga Listrik. Dielektrika Vol 1, No 1: 20- 24.

[2] Goenadi, Chandra. 2012. Analisis Keandalan Sistem Jaringan Distribusi 20kv di PT.PLN Distribusi Jawa Timur Kediri dengan metode Simulasi Section Technique. Jurnal teknik Pomits Vol 1, No.1: 1-6.

[3] SPLN 68-2 : 1986. Tingkat Jaminan Sistem Tenaga Listrik Bagian Kedua : Sistem Distribusi.

[4] WP Perdana, RN Hasanah, HS Dachlan. 2012. Evaluasi Keandalan Sistem Tenaga Listrik Pada Jaringan Distribusi Primer Tipe Radial Gardu Induk Blimbing. Jurnal EECCIS.

[5] D Dasman, H Handayani. 2017. Evaluasi Keandalan Sistem Distribusi $20 \mathrm{kV}$ menggunakan Metode Saidi dan Saifi Di PT.PLN (Persero) Rayon Lubuk Alung Tahun 2015. Jurnal Teknik Elektro-ITP.

[6] S Suparno. 2014. Komputasi untuk Sains dan Teknik Menggunakan Matlab. Universitas Indonesia.

[7] SB Wahyu. 2013. Aplikasi Perangkat Lunak berbasis Matlab Untuk Pengukuran Radiograf Digital. Jurnal Pendidikan Fisika Indonesia. 